the author has obtained many other organisms from this clay, and especially a large number of Foraminifera now in the hands of Prof. Karrer of Vienna. He estimates the total number of determinable species belonging to varions classes at over 200 .

In treating of his special subjects the author adopts the principles of classification laid down by Hincks, Smitt, and other recent writers on living Bryozoa, which he regards as preferable in themselves, and also as facilitating the comparison of fossil with recent forms.

\title{
OOREFSPONDENTCF.
}

\section{GLACIAL BOULDERS IN SECONDARY DEPOSITS, SIDNEY, NEW SOUTH WALES.}

Mr. C. S. Wilkinson, F.G.S., Government Geologist, Department of Mines, Sydney, N.S. Wales, referring to the occurrence of Glacial boulders in the "Hawkesbury Series," "w wites to Mr. R. Etheridge, jun., under date 10th February, 1881 :- "Here we have huge and small angular masses of soft shales embedded in pebble conglomerates and false-bedded sandstones. With these sandstones (Hawkesbury) aro interstratified argillaceous shales, and the boulders are of the same material and contain the same fossils. It seems that during the deposition of the Hawkesbury Series, the rapid and changing currents which deposited the false-bedded sandstones, were at intervals succeeded by quiet waters, from which the mud forming the shales settled down, probably during winter-time, when ground-ice formed. Spring-time following, the ice broke up, and drifting about broke up some of the newly-formed shales, and mingled the shale fragments with pebbles and sand brought by currents from the shores. The shale boulders are always found just above, or not far from the undisturbed shale-beds, thus :-

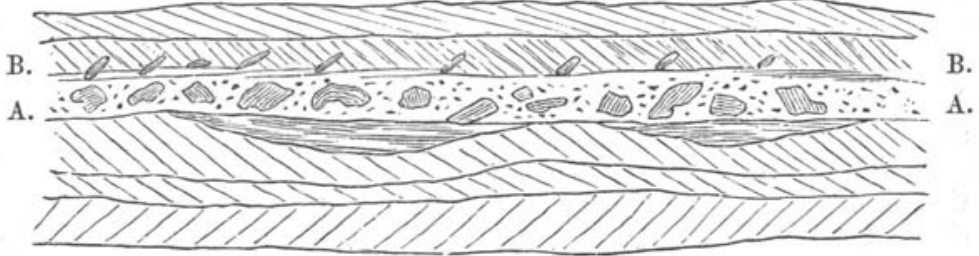

In the sandstones just above the bed with angular blocks $(A)$, are $(B)$ small rolled flattish pieces of the same shale, the longer diameter inclined in one position, showing the direction of the transporting currents at the time; some of the angular masses are curved, showing that they must have been in a soft condition, when torn up from the underlying shales. The principal fossils found in these are fragments of Plants-Phyllotheca, Thinnfeldia, Odontopteroides; Fishes-Palconiscus, Cheirolepis granulatus, Myriolepis Clarkii, and another, which appears to be new."

\footnotetext{
1 Lower Mesozoic.
} 